УДК: $378.014 .6: 015.6$

DOI: $10.15330 /$ esu. $15.130-136$
Андрій Танько,

кандидат юридичних наук, доцент, Харківський національний педагогічний університет імені Г.С. Сковороди (м. Харків, Україна)

Andrii Tanko, Candidate of juridical sciences ( $\mathrm{PhD}$ ),

Associate Professor, Kharkiv National Pedagogical University named after G.S. Skovoroda

(Kharkiv, Ukraine)

Tanko0300@gmail.com

\title{
ТЕОРЕТИЧНІ ОСНОВИ ФОРМУВАННЯ УПРАВЛІНСЬКОӤ КУЛЬТУРИ МАЙБУТНІХ МЕНЕДЖЕРІВ ОСВІТИ
}

\section{THEORETICAL BASES OF FORMING OF MANAGERIAL CULTURE OF FUTURE MANAGERS OF EDUCATION}

У даній статті розглянуто сутність теоретичної підготовки менеджера освіти, ї структуру та значення для формування управлінськой культури майбутнього фахівия; 3'ясовано сутність поняття "управлінська культура менеджера освіти"; визначено завдання, розкрито зміст навчальних дисциплін психолого-педагогічного блоку, запропоновано тематику спецкурсу, що сприятиме становленню та розвитку управлінсъкої культури студентів педагогічних вишів; наголочено на ролі і значущості позааудиторної роботи в чьому прочесі.

Ключові слова: менеджмент освіти, управлінська культура, навчально-виховний прочес педагогічного закладу вищої освіти, позааудиторна робота

The formation of the future manager of education, which Ukraine is waiting for, its professional self-realization in modern socio-cultural contexts, requires a high level of professional training, part of which is theoretical training, carried out primarily in the educational process. It takes place during the lectures and seminars where students receive the knowledge system which is necessary for the implementation of the functions of educational management in the professional-pedagogical activity. The analysis of scientific and pedagogical literature gives grounds to assert that the issue of comprehensive study of theoretical training of the future education manager of his role in the formation of his management culture did not find enough coverage.

Future teachers receive theoretical training both during the study of socio-humanitarian and psycho-pedagogical, and professional disciplines, as well as special courses. An analysis of existing curricula programs that are being studied in modern pedagogical educational institutions allowed us to find out that they do not provide solutions to the actual tasks of preparing a future teacher as a manager of education. Solving the tasks of forming the managerial culture of future teachers must be carried out by all disciplines of the sociohumanitarian cycle, which are presented and interpreted from the standpoint of the relevant field of knowledge for the formation of moral and legal consciousness, as well as from the general cultural positions. Extra-curricular work has a great potential for forming the managerial culture of the future manager of education. Its structure corresponds to the general structure of activity, and the motives (the purpose), actions (operations) - its concrete discovery. They find expression in educational actions, the structure of which includes goals, content, methods of education.

Key words: education management, managerial culture, educational process of higher educational institution, extra-curricular work. 
Постановка проблеми. Формування майбутнього менеджера освіти, на якого чекає Україна, його професійна самореалізація у сучасних соціокультурних контекстах вимагає високого рівня професійної підготовки, частиною якої $\epsilon$ теоретична підготовка, що здійснюється, насамперед, у навчальному процесі. Саме у ході лекційних і семінарських занять студенти отримують систему знань, необхідних для здійснення в професійно-педагогічній діяльності функції освітнього менеджмента. Величезне значення при цьому набуває позааудиторна робота (факультативи, гуртки, клуби тощо).

Аналіз наукових досліджень. До питання сутності освітнього менеджменту, його структури та ролі в навчальній діяльності в тій чи іншій мірі зверталися Б. Андрушків, О. Кузьмін, Б. Гаєвський В. Крижко, О. Мармаза та інші. Безпосередньо висвітленно проблеми позааудиторної роботи у теоретичній підготовці майбутнього менеджера освіти торкалися Л. Кондрашова, Л. Лисенко, О. Медведєва. Загальні питання компетентності майбутнього вчителя знайшли своє відображення у працях В. Лозової, Г. Троцко, Н. Побірченко.

Мета статті полягає у висвітлені теоретичних основ формування управлінської культури майбутніх менеджерів у навчально-виховному процесі педагогічних закладів вищої освіти.

Виклад основного матеріалу. Аналіз існуючих програм 3 дисциплін, що вивчаються студентами в сучасних вищих педагогічних закладах освіти дозволив 3'ясувати, що вони не можуть забезпечити вирішення актуальних завдань підготовки майбутнього вчителя як менеджера освіти. Теоретичні знання щодо формування управлінської культури у майбутніх менеджерів освіти мають бути спрямовані на вирішення таких завдань:

- у циклі соціогуманітарних дисциплін - поглиблення загальної інкультурації особистості студента, напрацювання умінь і навичок його власної практики 3 інкультураційної роботи такого ж роду;

- у циклі психолого-педагогічних дисциплін - засвоєння й присвоєння основних елементів загальної, педагогічної, професійної культури, основ організаційної культури та культури управління освітнім процесом, в основу яких покладено знання про духовну, моральну та правову, свідомість особистості як іiї цінності.

Вирішення завдань інкультураційного профілю має здійснюватися всіма дисциплінами соціогуманітарного циклу: філософією, етикою, історією, соціологгією, політологією, теорією та історією держави та права, логікою, юридичною деонтологією, адміністративним, кримінальним, цивільним, податковим правом та основами інтелектуальної власності, в межах яких мають порушуватися питання культурного аспекту кожної з цих галузей знання 3 метою формування моральної та правової свідомості та формування управлінської культури майбутнього вчителя.

Особлива роль у вирішенні названого завдання належить власне культурології як науковій дисципліні й навчальному предмету, який вводить студента в загальну теорію культури, питання морфології й динаміки культури, іiі соціальних функцій та механізмів функціонування, соціокультурних норм і цінностей суспільного буття.

Провідне місце в трансляції культури, іiї перетворенні на особистісно-управлінську культуру майбутнього менеджера освіти належить психолого-педагогічному блокові дисциплін, спрямованому на розвиток самосвідомості майбутнього вчителя, його творчої реалізації й рефлексії педагогічної діяльності. Оскільки становлення "Я" конщепція майбутнього-менеджера освіти - це не однозначний акт, цей блок поданий орієнтувальним, теоретико-методологічним та діяльнісним модулями. 
Модернізація змісту педагогічних дисциплін передбачає врахування єдності таких методологічних підходів, як культурологічний, особистістно-діяльнісний та антропологічний.

Перший має можливість розглядати динаміку педагогічний ідей i теорій у контексті світової культури, другий дозволяє визначити мету підготовки, становлення особистості вчителя як суб'єкта педагогічної діяльності й управлінської культури, третій розглядає людинознавство як основу педагогічної діяльності, фахової компетентності й методологічної культури вчителя.

Визначальна роль у побудові змісту педагогічної освіти відведена ант ропологічному принципу, який орієнтує педагогіку на індивідуальність, на власне людське в людині, ऑiі духовну та морально-правову сутність.

Культурологічний підхід під час відбору змісту навчальних дисциплін педагогічного блоку вимагає його усвідомленого підпорядкування культуроутворюючій меті та передбачає:

- розгляд освіти як соціокультурного феномена, який являє собою, з одного боку, соціокультурний інститут, а 3 іншого - антропогенну практику культури;

- визначення освіти i виховання як основ загальнолюдської культури в сполученні з вимогами, які йдуть від інтересів розвитку того, хто навчається, й педагогічної науки;

- усвідомлення сутності освіти та виховання як єдиного процесу 3 тими, хто навчається, організація їх життя на рівні культури;

- усвідомлення майбутнім учителем культурних сенсів педагогічної діяльності;

- відображення в змісті освіти ціннісного, діяльністного, й особистіно-творчого компонентів управлінської культури, які сприяють у своєму розвиткові цілісності культури майбутнього вчителя;

- постійне збагачення особистості майбутнього менеджера освіти необхідним досвідом виконання функцій суб’єкта культури управління та управлінської культури.

Становленню та розвитку управлінської культури студентів-майбутніх менеджерів освіти сприятиме й впровадження у навчальний процес спеціального курсу, в якому 3 культурологічних та педагогічних позицій мають висвітлюватися такі питання:

- правова культура як підгрунтя культурологічної підготовки майбутнього вчителя;

- загальна культура студента як фундамент для розвитку особистості;

- педагогічна культура як частина загальнолюдської культури;

- філософсько-гуманістичні основи управлінської культури;

- соціокультурна функція педагогічної діяльності; історія становлення загальної культури, педагогічної, професійної, організаційної культури вчителя;

- педагогічна культура як сутнісна характеристика особистості вчителя, iii складники;

- професійна культура 3 позиції характеристики педагогічної діяльності та спілкування вчителя;

- організаційна культура вчителя - менеджера освіти;

- культура управління освітнім менеджментом;

- шляхи розвитку й саморозвитку особистісної управлінської культури менеджера освіти. 
Цей спецкурс, виконуючи професійно-орієнтаційну та мотиваційну прогностичну функцію в підготовці вчителів - майбутніх менеджерів освіти сприяє посиленню культурної спрямованості особистості майбутнього вчителя, відкриває перспективу його творчої самореалізації в педагогічні спеціальності й подальшого зростання як менеджера освіти.

Великі можливості для формування управлінської культури майбутнього менеджера освіти має позааудиторна робота.

У розділі про особливості виховного процесу у закладі вищої освіти “концепції виховання дітей та молоді в національній системі освіти" [8] зазначається, що вищі навчальні заклади мають здійснювати підготовку свідомої національної інтелігенції, сприяти оновленню i збагаченню інтелектуального генофонду нації, який забезпечить високу ефективність діяльності майбутніх спеціалісті. Це повинно бути досягнуто через формування "Я" - концепції людинитворця на основі самоосвіти, саморозвитку, самовиховання, самовдосконалення студентів. Це $є$ переконливим свідченням значення позааудиторної роботи студентів для професійно-особистістного становлення майбутнього фахівця, спроможного вирішувати найскладніші завдання суспільного життя.

Безсумнівно, для ефективного застосування потенційних можливостей позааудиторної роботи студентів щодо формування у них управлінської культури необхідно визначити іiі основні характеристики, специфіку організації, 3'ясувати особливості іiі здійснення на окремих етапах професійного становлення майбутнього фахівця.

Позааудиторна робота студента є продовженням аудиторної роботи, а може бути й окремим елементом у процесі підготовки майбутніх педагогічних кадрів студентів. Найбільш доцільним підходом до розгляду позааудиторної роботи студентів виявляється системний підхід, оскільки ми погоджуємося 3 тими авторами, які відносять позааудиторну діяльність до категорії систем, тобто цілісних утворень, що складаються із взаємопов'язаних елементів (Л. Кондрашова, В. Лозова, О. Медведєва, О. Мармаза, Г. Троцко та ін.) $[7 ; 11 ; 12 ; 13]$.

У позааудиторній роботі поєднуються різноманітні види праці та спілкування, реалізуються різнобічні як виховні, так i навчальні завдання, спрямовані на професійну підготовку майбутнього фахівця, в тому числі й на формування його управлінської культури.

Отже позааудиторну роботу у педагогічному закладі вищої освіти ми розглядаємо як систему навчально-виховних заходів, яка $\epsilon$ невід'ємною складовою у процесі професійно-педагогічної підготовки майбутніх учителів і здійснюється 3 метою створення умов для інтелектуального, духовного, та професійного розвитку студентів, їх самореалізації.

Незважаючи на тісний зв'язок з аудиторною роботою, позааудиторна робота має свої відмінності:

- участь студентів у позааудиторній роботі має добровільний характер, на навчальних заняттях - обов'язковий;

- позааудиторні заходи носять невимушений характер;

- різноманітні позааудиторні заходи виключають контроль у вигляді оцінок умінь, навичок, знань та наявність єдиної програми;

- позааудиторна робота у порівнянні з аудиторною надає більші можливості для прояву самостійності студентів, їх ініціативи та творчості. 
Як наслідок, вірно організована i раціонально спланована позааудиторна робота студента забезпечує найбільш високий рівень засвоєння матеріалу трасформацію, є засобом активізації інтелектуальною діяльністю, розвитку творчих здібностей, формувань творчих умінь [10, с. 126-129].

Мета позааудиторної роботи - розвиток різнобічних інтересів і здібностей студентів, прищеплення навичок трудової та суспільної діяльності; виховання самостійності та відповідальності, потреби в знаннях, уміннях, інтересу до науки, техніки, мистецтва, літератури; організація розумового дозвілля; зміцнення здоров'я молоді.

Якщо в аудиторний час діяльність студента знаходиться під безпосереднім керівництвом викладача, то в позааудиторний час вихованець у більшій мірі сам керує процесом оволодіння знаннями, формуванням умінь і навичок.

Разом з тим позааудиторна робота студентів педагогічних закладів освіти має свою специфіку. Основна специфічна особливість позааудиторної роботи студентів вишів педагогічного профілю зумовлюється специфікою професійнопедагогічної підготовки майбутнього вчителя, яка передбачає оволодіння не тільки спеціальними знаннями і вміннями зі свого предмету, але й оволодіння сукупністю професійних компетенцій та особистісних якостей, необхідних для управління цілісним навчально-виховним процесом в умовах сучасної школи, які постійно ускладнюються через зростання вимог суспільства до системи освіти.

Отже ми погоджуємося 3 думкою С. Вітвицької про те, що роль і значення позааудиторної роботи для формування управлінської культури майбутнього менеджера освіти полягає в тому, що вона стимулює формування особистості майбутнього педагога у контексті професіоналізації всіх виховних впливів на студентів. [3, с. 122].

Професіоналізація позааудиторної роботи вміщує з одного боку, "спеціалізацією" тобто врахування специфіки факультету, а з іншого - "педагогізацію", яка враховує загальну професіограму вчителя, надаючи всій системі навчальновиховної роботи у вищій школі педагогічної спрямованості, широко застосовуються в практиці виховання приклади із професійної діяльності.

На особливості організації позааудиторної роботи студентів впливає низка факторів, зокрема:

- режим навчально-виховного процесу закладу вищої освіти.

- тривалість термінів навчання, що зумовлює зміст, інтенсивність та плани проведення позааудиторних навчально-виховних заходів;

- специфічність студентського контингенту, його соціальні, демографічні, вікові, психолого-фізіологічні, гендерні та інші особливості;

- специфічність професорсько-викладацького складу, рівень його фахової та психолого-педагогічної підготовки.

Ученими $[1 ; 4 ; 7]$ проаналізовано обсяг та структура позааудиторної роботи студентів у закладах вищої освіти, розроблено елементи іiі планування та організації, досліджено бюджет часу студентів; вивчено фізіологічні та гігієнічні основи організації позааудиторної роботи, проаналізовано шляхи вдосконалення методики формування в студентів культури навчальної праці та методики формування вмінь і навичок роботи в позааудиторний час.

Нами визначено принципи організації позааудиторної роботи 3 метою формування управлінської культури студентів у сучасному педагогічному вузі, основними з яких $€$ : 
- гуманізація, гуманітаризація та гармонізація всіх напрямів професійної підготовки майбутнього менеджера освіти;

- системність й цілісність навчально-виховного процесу;

- науковість;

- орієнтація на розвиток у студентів лідерський якостей;

- забезпечення творчого характеру позааудиторної роботи;

- постійне оновлення змістовної та ускладнення процесуальних сторін позааудиторної роботи.

Позааудиторна робота студентів сприяє розвитку особистісних якостей, що притаманні менеджеру освіти, а саме: формуванню високоморальної й інтелекттуально розвиненої особистості, яка здатна до швидкої та безболісної адаптації до складних умов реального навчально-виховного процесу школи; розкривати, аналізувати й активно використовувати свої потенційні можливості, здійснювати самоменеджмент.

Висновки та перспективи подальших досліджень. Отже, у процесі навчально-виховної та позааудиторної роботи педагогічних вишів відбувається соціальне і професійне становлення особистості майбутнього менеджера освіти, формування його ціннісних оріснтацій управлінської культури, повне розкриття творчої індивідуальності як єдності інтелектуальності. У сучасному навчальновиховному процесі закладів вищої освіти актуалізується побудова навчальновиховного процесу та позааудиторної роботи студентів таким чином, щоб створювати умови для максимального розвитку кожного майбутнього фахівця своїх потенційних лідерських якостей. Подальших наукових пошуків потребує аналіз науково-методичного забезпечення здійснення процесу формування управлінської культури студентів педагогічного профілю, віднайдення варіативних та альтернативних форм і методів навчально-виховної роботи.

\section{Література}

1. Андрушків Б. М., Кузьмін О. Є. Основи менеджменту. - Львів: Світ, 1995.-296 с.

2. Васильєва М. П. Теорія педагогічної деонтології. - Харків.: Нове слово, $2003-216$ с.

3. Вітвицька С. С. Основи педагогіки вищої школи: методичний посібник для студентів магістратури. - К.: Центр навчальної літератури, 2003. $-316 \mathrm{c}$.

4. Гаєвський Б. Основи науки управління: навч.посібник. - К.: МАУП -1997. - 112 С.

5. Гриньова В. М. Формування педагогічної культури майбутнього вчителя (теоретичний та методичний аспект). - Харків: Основа, 1998. - 300с.

6. Классическая педагогика: учебное пособие / Л. С. Нечепоренко, Я. В.Подоляк, В. Г. Пасинюк. - Х.: Основа, 1998. - 420с.

7. Кондрашова Л.В. Внеаудиторная работа по педагогике в педагогическом институте. Одесса: Вища школа, 1998. - 158 с.

8. Концепція виховання дітей та молоді в національній системі освіти // Інформаційний збірник Міністерства освіти України. - 1996. - № 13. - С.3-9.

9. Крижко В. В. Теорія та практика менеджменту в освіті. - Запоріжжя: Просвіта, 2003. - 272 с.

10. Лисенко Л. В. Організація позааудиторної виховної роботи в студентській групі // Напрями наукових досліджень кафедри педагогіки: педагогіка і психологія: збірник наукових праць. Х., 1997. -Вип.4. - С. $126-129$.

11. Лозова В. І., Троцко Г. В. Теоретичні основи виховання і навчання: навчальний посібник для студентів педагогічних навчальних закладів. - Харків, 1997. -338 с.

12. Мармаза О. І. Менеджмент в освіті: секрети успішного управління. - Харків, 1997. - 338 с.

13. Медведєва О.Р. Формування творчих умінь студентів у поза аудиторній виховній роботі: Дис. ... канд..пед.наук: 13.00.04 - Харків, 2006. - 266 с.

14. Побірченко Н. Інноваційні підходи до підготовки майбутніх учителів у контексті реформування системи вищої освіти // Рідна школа. - 2003. - № 3. - С.3-5.

15. Ушинський К. Д. Три елемента щколы //Собр.соч.: В 11 т. - М.: Изд-во АПН РСФСР, 1948. T. 2. $666 \mathrm{c}$.

References

1. Andrushkiv B., Kuzmin O. Fundamentals of Management. - Lviv: Svit, 1995.-296 p. 
2. Vasylyeva M. Theory of Pedagogical Deontology. - Kharkiv.: Nove slovo, $2003-216 \mathrm{p}$.

3. Vitvytska S. Fundamentals of Pedagogy of the Higher School: a methodical manual for the students of the magistracy. - K.: Center for Educational Literature, 2003. $-316 \mathrm{p}$.

4. Havevskyy B. Principles of science of management: a manual. - K.: MAUP -1997. - $112 \mathrm{p}$.

5. Hrynova V. Formation of the pedagogical culture of the future teacher (theoretical and methodical aspect). - Kharkiv: Osnova, 1998. -300 p.

6. Classical Pedagogy: Textbook/ L. Necheporenko, Y. Podolyak, V. Pasynyuk. - Kh.: Osnova, 1998. $-420 \mathrm{p}$.

7. Kondrasova L. Non-audit work on pedagogy at the pedagogical institute. - Odessa: Higher school, 1998. - $158 \mathrm{p}$.

8. Concept of education of children and youth in the national education system // Informational collection of the Ministry of Education of Ukraine. - 1996. - № 13. - p.3-9.

9. Kryzhko V. Theory and practice of management in education. - Zaporozhye: Prosvita, 2003 - 272 p.

10. Lysenko L. Organization of non-auditing educational work in a student group // Directions of scientific research of the Department of Pedagogy: Pedagogy and Psychology: a collection of scientific works. - Kh., 1997. - Issue .4. - P. 126 - 129.

11. Lozova V., Trotsko G. Theoretical foundations of education and training: a manual for students of pedagogical educational institutions. - Kharkiv, 1997. $-338 \mathrm{p}$.

12. Marmaza O. Management in education: the secrets of successful management. - Kharkiv, 1997. $338 \mathrm{p}$.

13. Medvedyeva $\mathrm{O}$. R. Formation of creative abilities of students in extra-curriculum educational work: The dissertation of the candidate of pedagogical sciences: 13.00.04 - Kharkiv, 2006. - 266p.

14. Pobirchenko N. Innovative approaches to the training of future teachers in the context of reforming the system of higher education // Ridna shkola. - 2003. - № 3. - p.3-5.

15. Ushinsky K. Three elements of the school// Collection of essays: In 11 volumes - M $\therefore$ Publishing House of Academy of Pedagogical Sciences of the RSFSR, 1948. - T. 2. 666 p.

Одержано статтю: 6.03 .2019

Прийнято до друку: 9.04.2019

УДК 378.14

DOI: $10.15330 /$ esu. 15.136-144

\section{Свдокія Харькова,}

кандидат педагогічних наук, доцент, Сумський державний педагогічний університет імені А.С.Макаренка (м. Суми, Україна)

\section{Yevdokiia Kharkova,}

Candidate of pedagogical sciences (PhD), Associate Professor, Sumy Makarenko state pedagogical university (Sumy, Ukraine) tdljrbz65@ukr.net

\section{Наталія Павлущенко,} кандидат педагогічних наук, доцент, Сумський державний педагогічний університет імені А.С.Макаренка (м. Суми, Україна)

Nataliia Pavlushchenko, Candidate of pedagogical sciences $(\mathrm{PhD})$, Associate Professor, Sumy Makarenko state pedagogical university (Sumy, Ukraine) pavnm1972@ukr.net

\section{ОСОБЛИВОСТІ ПЦДГОТОВКИ МАЙБУТНІХ ВИХОВАТЕЛІВ ДО ПРОФЕСІЙНОГО САМОРОЗВИТКУ}

\section{PECULIARITIES OF TRAINING OF FUTURE PRESCHOOL TEACHERS FOR PROFESSIONAL SELF-DEVELOPMENT}

Проаналізовано теоретичні основи проблеми саморозвитку майбутніх вихователів в сучасній системі освіти. Розкрито питання професійного саморозвитку майбутніх 